\title{
Identifikace mobilizačních témat Dělnické strany sociální spravedlnosti skrze analýzu sociálních médií ${ }^{1}$
}

\author{
Identification of Workers' Party of Social Justice (DSSS) mobilization issues \\ using a social media analysis
}

\author{
JAN HANZELKA ${ }^{2}$
}

\begin{abstract}
The article 'Identification of Workers' Party of Social Justice (DSSS) mobilization issues using a social media analysis" is focused on using the analysis of data obtained from social media in political science and security research, specifically research of mobilization issues of the Czech far-right Workers' Party of Social Justice (DSSS) political party. Based on the theoretical framework and using a combination of content and framework analyses of their Facebook page, we tried to identify and describe the mobilization issues that this party uses, and which also have high response from the supporters of the party. The results show that in the last three years a rapid change can be seen in the mobilization potential associated with a shift from anti-Roma mobilization issues to issues oriented against immigration and Islam. General mobilization is then built on the principle of negation and delimitation towards other actors, especially the current establishment, and is based on a feeling of injustice.
\end{abstract}

Keywords: Extremism; Far Right; Cyber Security; Mobilization; Content Analysis; Online Social Networks; Radicalization; Frame Analysis; Social Media

\section{1. Úvod}

Průměrný uživatel kontroluje svůj mobilní telefon kvưli novým zprávám a notifikacím jednou za šest minut (Knott 2015: 2). Není tedy prŕliš překvapivé, že nástroje a technické možnosti, které přišly s Webem 2.0 a sociálními médii,

\footnotetext{
1 Text byl zpracován $\mathrm{v}$ rámci projektu specifického výzkumu Katedry politologie FSS MU „Aktuální problémy politologického výzkumu II. (kód MUNI/A/1110/2015)“.

${ }^{2}$ Interní doktorand, Katedra politologie, Fakulta sociálních studií, Masarykova Univerzita, Česká republika / Department of Political Science, Faculty of Soocial Studies, Masaryk University, Brno, Czech Republic. Contact: jan.hanzelka@mail.muni.cz.
} 
se uchytily u politických stran, hnutí a skupin rozličných ideologických směrů, které tak mohou daleko efektivněji a jednodušeji šírit své myšlenky a mobilizovat své př́znivce (Turner 2013: 381), čehož rovněž mohou využívat různé radikální a extremistické názorové proudy, at' už jde o politicky nebo nábožensky orientované organizace a hnutí. Cílem tohoto článku by mělo být nalezení hlavních mobilizačních témat a rámců, které používá Dělnická strana sociální spravedlnosti (DSSS), a na základě dat získaných s facebookového profilu strany se pokusit o analýzu odezvy těchto témat. Pokusím se tedy nalézt odpověd’ na výzkumnou otázku: „Jaká mobilizační témata jsou úspěšná př̀ mobilizaci př́znivců této strany?"“.

Prostředí české krajní pravice bylo vybráno z několika důvodů. Zaprvé, porozumění a monitoring používání sociálních médií krajní pravicí je uvedeno jako jeden z výzkumných cílů budoucích let a tento trend nebyl doposud dostatečně podroben na poli politologie, respektive bezpečnostních studií, ucelenějšímu výzkumu (viz Ramalingam 2014). Druhým důvodem pro výzkum na poli české krajně pravicové scény je skutečnost, že se jedná o otázku velmi aktuální, jelikož lze očekávat možné tendence růstu popularity politických stran a hnutí spojených s protiimigračními náladami, přičemž právě sociální média jsou jimi používána jako prvoliniový nástroj pro šíření propagandy a $\mathrm{k}$ mobilizaci př́znivců. Sociální média se tak stala nejen nástrojem mobilizace, ale i zdrojem dat, který dokáže mapovat aktivitu těchto hnutí či organizací a jejich prríznivců, stejně jako sledovat aktuální mobilizační praktiky a témata nejen z pohledu toho, jak jsou předkládána do veřejného prostoru, ale rovněž jak jsou prrijímána. Př́pad Dělnické strany sociální spravedlnosti (DSSS) byl vybrán z důvodu charakteru subjektu jakožto nejstabilnějšího z ideové rodiny krajní pravice v České republice, který zároveň na sociálních médiích disponuje největším počtem příznivců.

Proč se ale hlouběji zabývat konkrétně studiem sociálních médií? V prvé řadě poskytují online sociální sítě těmto organizacím levný prostředek šíření informací, který díky masové popularitě těchto webů může potencionálně oslovit mnohonásobně větši populaci, než tomu bylo doposud. Dalším důvodem ke studiu je možnost zaměření se na tyto skupiny nikoliv „shora“ a klasicky studovat jejich strukturu, historii, program atd., ale nabízí se možnost získávaní informací „zdola“ o nestrukturovaných skupinách a komunitách. I proto se ve vedlejších výzkumných otázkách budu zabývat tím, jak se DSSS chová na svém facebookovém profilu (jaký druh obsahu a v jaké intenzitě ho publikuje) a jak se chovají prŕżnivci strany (jaká je aktivní základna, jaká je průměrná uživatelská aktivita a jaký druh obsahu uživatele prritahuje). 


\section{Teoretický základ a současný stav výzkumu}

\section{a. Současný výzkum krajní pravice v prostředí sociálních médií}

Již dlouhou dobu probíhají výzkumy, které se zaměřují na aktivitu krajní pravice v prostředí internetu. Obecně lze tyto práce rozdělit do dvou kategorií. Do první patří studie, které se snaží sít'ovou analýzou zjistit klíčové uzly a vazby mezi jednotlivými weby, blogy a uživateli (Chau a Xu 2007; Bermingham a kol. 2009; Burris a kol. 2012). Druhou kategorii pak tvoří výzkumy, které využívají webové prostředí jako zdroj informací, jež jsou dále zpracovávány např́lklad obsahovou analýzou, at' už kvalitativní či kvantitativní. Za všechny jmenujme práce, které se zaměřují na výzkum politického diskursu (Ferber 2000), extrémistické rétoriky (Thiesmeyer 1999; Barnett 2007), analýzu blogů (Cammaerts 2009) a především pak př́spěvek analyzující mobilizaci a utváření komunity (Ciani a Wagermann 2012). Sociální média jako je Facebook, Twitter nebo Youtube však zůstávala při výzkumu radikálních a extrémních politických proudů dlouho nepovšimnuta. Za určitý zlom můžeme považovat rok 2011, který ukázal medializační a mobilizační potenciál nových médií a sociálních sítí. Německá krajně pravicová skupina Die Unsterblichen (Nesmrtelnî) tehdy zahájila svou kampaň „Staň se Nesmrtelným“ právě za využití sociálních sítí (viz Peters 2015). Mezi práce zaměřující se na sociální sítě je možné zařadit např́klad práci O’Callaghan a kol. (2012), který analyzoval data $z$ Twitteru a snažil se popsat mezinárodní sít' krajně pravicových organizací na základě jejich vzájemných vztahů. Dále pak Mattias Ekman (2014) ve svém článku analyzoval videomateriály získané z Youtube, která následně obsahovou analýzou ,škatulkoval“ do vydefinovaných kategorií.

$\mathrm{V}$ českém prostředí se můžeme setkat $\mathrm{s}$ výzkumem zaměřeným na krajně pravicové weby (Avukatu a Lupáč 2014), které byly analyzovány za pomoci sít’ové analýzy vystavěné na základě vzájemného odkazování mezi jednotlivými weby a blogy. Autoři rovněž zmiňuji možnost dalšího výzkumu právě v oblasti nových médií. Další práce autora Holase (2013), Politický radikalismus a mládež, se zaměřila podrobněji na obsahovou analýzu jednotlivých webů z hlediska tematického zaměření a mobilizačních témat. $V$ tomto textu navážu na výše uvedené příspěvky a rozšírím oblast výzkumu právě o sociální média (konkrétně nejrozšířenější online sociální sít' Facebook), které nebudu chápat pouze jako zdroj informací, ale i jako specifický prostor pro jejich šíření. Rovněž navážu na práci Metta Goldera (2016) a pokusím identifikovat střed poptávky po krajně pravicové politice a nabídky DSSS právě na poli sociálních médií.

\section{b. Sociální média jako nástroj mobilizace}

Sociální média se stala nástrojem aktivismu a politickou arénou, která však může mít stejně jako v reálném světě velmi negativní stránku. Ta se může odrážet právě v podobě šírení radikalismu a extremismu (Choo 2011; Peters 2015; Feischmidt 
a Hervik 2015). Politické akce a organizace se staly díky sociálním médiím mnohem snadnějš́i i pro menší skupiny (Copsey 2003; Van Aelst, Walgrave 2002; Cammaerts 2012). Tyto sítě usnadňují komunikaci s potencionálními ideovými přivrženci extremistických a radikálních skupin, které vyznávají názory potlačující základní lidská práva, at' už se jedná o skupiny vyznávající náboženský extremismus nebo extremismus politický, a rovněž se mohou stát počáteční ideovou základnou a akcelerovat radikalizaci jednotlivých prŕínivců (Feischmidt a Hervik 2015). Sociální média poskytují prostor pro vytváření kolektivní identity sdílením podobných názorů, zdrojů informací a vzájemné solidarity $\mathrm{k}$ určitému pohledu na svět (della Porta a Mosca 2006: 538). Zároveň nabízí možnost radikálním členům společnosti vyhledat stejně smýšlející jedince a následné zjištění, že jejich pohled na věc je sdílený a má více př́znivců, může být velkým krokem v osobní radikalizaci (Post 2005). Dnešní politická uskupení a tzv. nová hnutí si tedy plně uvědomují důležitost sociálních médií při budování základny podporovatelů a členů. Sociální média dovolují budovat sít' podporovatelů jak na národní, tak na mezinárodní úrovni; jsou tedy efektivním nástrojem politické mobilizace. Nástrojem, který je v porovnání s kampaněmi minulosti extrémně levný a extrémně rychlý, je umožněna komunikace $\mathrm{v}$ reálném čase. Empirický výzkum skupiny autorů okolo Jinga Wanga (2015) prokázal, že rychlost mobilizace přes Facebook je výrazně vyšší než s využitím emailové komunikace. V neposlední řadě sociální média dle Turnera (2013: 379) nabízí „....nový nástroj rámcování a změn, které mají efekt na nastavení politické diskuze a diskursu." Zaměŕím se tedy na tento jev skrze případ DSSS, kterou bychom mohli přriřadit na základě předchozích výzkumů do krajně pravicového spektra.

\section{c. Př́pad Dělnické strany sociální spravedlnosti}

V krátkosti si shrňme historii a genezi DSSS z dřivější Dělnické strany. Dělnická strana (DS) byla založena roku 2002 s tehdejším názvem Nová síla. O rok později byla strana přejmenována na DS a do jejího čela se postavil Tomáš Vandas. Zpočátku marginální uskupení začalo vzbuzovat zájem vlády, médií a bezpečnostních složek, a to díky své programatice založené na ostrém vymezování se vůči „nepřizpůsobivým občanům“ a úzkým vazbám na českou neonacistickou scénu. Situace začala eskalovat od roku 2008, kdy strana začala organizovat polovojenské tzv. Ochranné sbory, které měly „dohližet“ na lokality s častým výskytem střetů mezi etnicky českou majoritou a romskou minoritou. V roce 2009 proběhla masové demonstrace v Janově a tzv. „Bitva o Janov“, která skončila střety s policií, kterých se zúčastnily již zmíněné Ochranné sbory, což můžeme považovat za pomyslnou poslední kapku, která vyústila v podání vládní žádosti na rozpuštění strany (Mareš 2011: 37-39; Mareš a Vejvodová 2010). Tato žádost byla Nejvyšším správním soudem posouzena jako opodstatněná a strana byla 17. února rozpuštěna (viz Rozsudek Nejvyššího správního soudu 2010). 
Vzápětí však byla strana obnovena pod názvem DSSS. Můžeme konstatovat, že po rozpuštění DS došlo $\mathrm{k}$ programovým posunům blíže $\mathrm{k}$ demokratickému středu, což však nemusí znamenat v souvislosti s chováním strany pozitivní efekt. Do velké míry se jednalo pouze o záplatování děr, které se ukázaly v soudním procesu jako protiprávní, nebo přinejmenším jdoucí proti základním hodnotám demokratického systému.

DSSS, jak už bylo řečeno, v minulých letech stavěla svůj program především na protiromské tématice a tématu zneužívání sociálního systému, což straně přineslo lokální popularitu $\mathrm{v}$ oblastech $\mathrm{s}$ výskytem sociálně vyloučených lokalit (např́klad Severní Čechy), kde se účastnila a politicky těžila z místních demonstraci zaměřených proti kriminalitě (Mareš 2012, 2015). Strana jako taková však nikdy nezískala větší zisky ve volbách a to i kvưli tomu, že je s ní spojován právě př́klon $\mathrm{k}$ extremismu, čímž DSSS odrazuje ty voliče, kteří jsou blíže $\mathrm{k}$ mainstreamu (Mareš a Vejvodová 2010). Této „nálepky“ se strana pokoušela zbavit právě během demonstrací, kdy se snažila poukazovat na př́tomnost „obyčejných“ občanů (DSSS 2015). K jistým posunům přesto došlo ve vztazích s ostatními subjekty převážně neonacistické scény, od kterých si nyní strana drží větší odstup; jak jsme ale mohli pozorovat $\mathrm{v}$ době protiromských protestů na severu Čech (především v roce 2013), stále dochází ke střetům s policií a strana si při prípadných násilných konfliktech udržuje postavení politického podnikatele (viz např́ílad Tilly 2006), který čerpá podporu z pocitu nedostatečného zájmu státu o místní problémy a může být jedním z eskalátorů prípadného konfliktu. Pokud jde o současné ideologické směřování této strany, tak Háka (2016) ve své analýze postoje DSSS k liberální demokracii zjistil, že strana naplňuje Sartoriho koncept antisystémové strany. Co se pak týče vlivu strany na samotný politickostranický systém, díky nízkým volebním výsledkům se strana nikdy nedostala do pozice, kdy by mohla sama o sobě prosazovat legislativní změny nebo by získala vyděračský potenciál (Sartori 2005). Obecně pak je česká krajní pravice v stagnaci a útlumu (což potvrdily i výsledky krajských voleb 2016), a to i díky silnému zájmu státních represivních orgánů o krajně pravicové spektrum. DSSS přesto zůstává nejvýraznějším subjektem české krajně pravicové scény, ač lze diskutovat o možném ohrožení ze strany nových populistických uskupení, které se svou programatikou prolínají s myšlenkami krajní pravice. Jde zejména o nová hnutí, která svůj program staví z velké části na odporu vưči imigraci a často nechybí ani silný antisystémový apel. Jde např́íklad o uskupení Úsvit - Národní Koalice, Svoboda a prímá demokracie (SPD) nebo Blok proti islamizaci, které mohou zlákat část voličů, pro něž mohou představovat alternativu DSSS, a to bez nálepky krajně pravicové strany.

Zaměŕíme-li se na mobilizačním témata DSSS, jak byly popsána $\mathrm{v}$ dřívější literatuře, Mareš (2012: 7) uvádí, že DSSS se hlásí k národnímu socialismu, přičemž část členské základny i sympatizantů strany má tendence k izolacionismu či xenofobnímu nacionalismu; $\mathrm{v}$ jejich řadách se objevují příznivci českého 
husitského nacionalismu, ale narážíme i na spojení s neonacistickým spektrem prostřednictvím odkazů na nacistické Německo. Strana rovněž dlouhodobě podporuje tradiční rodinu a odmítá registrované partnerství. DSSS př́mo nezpochybňuje prvky a mechanismy parlamentární demokracie, ale prosazuje demokracii prrímou. Dalším důležitým prvkem je zaměření na otázku „cikánské kriminality“, kdy se staví proti Romům. Posledním bodem je „welfare šovinismus“, tedy preference podpory státu pro vlastní etnikum.

\section{Metodologie}

V prvním stupni analýzy se zaměŕím na charakteristiku chování strany a př́znivců strany na Facebooku a následně na základě průměrné odezvy interakce mezi uživateli a DSSS vyfiltruji nadprůměrně hodnocené př́spěvky, které budou využity pro obsahovou a rámcovou analýzu. Ta by nám měla ukázat, jaká témata DSSS prezentuje a zároveň jaká mobilizační témata mají ohlas u komunity, která se okolo této strany na Facebooku vytvořila. Stejně tak se vyjasní, jaký rámec se vytvořil okolo těchto témat v podobě, v jaké jsou prezentována DSSS.

Dataset byl sestaven okolo aktivity oficiálního profilu DSSS na Facebooku. Orientace sběru dat je tedy zaměřena na subjekt DSSS a aktivitu uživatelů spjatou s touto stranou (uživatelské operace). K extrakci dat byla využita aplikace Netvizz, kterou vyvinul Bernard Rieder (2013). Počáteční dataset se skládal z 1255 př́spěvků. Ty budou $\mathrm{v}$ prvotní fázi výzkumu sloužit $\mathrm{k}$ zjištění vzorců chování uživatelů a strany na Facebooku. Co se týká časového vymezení, z důvodu množství dat a jejich technické dostupnosti jsme zvolili časový úsek téměř tří let (od 1. 1. 2013 do 5. 9. 2015). Tento časový úsek nabízí dostatečný rozsah, na kterém by se měly projevit změny mobilizačních témat, což je umocněno volbami do Poslanecké sněmovny v ř́jnu 2013.

$\mathrm{V}$ pokročilejši fázi analýzy byl dataset vyfiltrován na př́spěvky s největší odezvou od uživatelů. Vybrány byly prríspěvky s nadprůměrnou odezvou, což se v praxi rovnalo 230 př́spěvkům, tedy více než 108 uživatelským operacím (veličina $y$ ve vzorečku níže) na prŕspěvek. Celkový počet uživatelských interakcí pak můžeme definovat jako souhrn všech komentárư (comments), sdílení (shares) a „lajkü“ (likes), které se vážou $\mathrm{k}$ danému profilu (viz vzoreček níže). Tyto př́spěvky byly následně analyzovány více do hloubky, prostřednictvím kvalitativní obsahové a rámcové analýzy.

$$
\left.\mathrm{y}=\sum \text { (likes }+ \text { comments }+ \text { shares }\right)
$$

Selekcí nadprůměrně uživatelsky přijímaných prríspěvků budou výsledky analýzy ,zkresleny“ námi požadovaným směrem, a to k určení tematických rámců $\mathrm{s}$ vyšším mobilizačním potenciálem.

Obsahová analýza je multioborovou, široce užívanou kvalitativní výzkumnou technikou, která však má mnoho forem a způsobů aplikace. Pokud bychom se 
drželi rozdělení, které představily ve svém článku autorky Hsiu-Fang Hsieh a Sarah E. Shannon (2004), a to na konvenční obsahovou analýzu, řízenou obsahovou analýzu a souhrnnou obsahovou analýzu, tak v této práci zvolíme právě obsahovou analýzu souhrnnou. Ta se vyznačuje především tím, že kódy nejsou předem vystavěny, ale jsou tvořeny, rozšiřovány, slučovány a rušeny během procesu kódování (induktivní postup). Obecně pak můžeme každou obsahovou analýzu považovat za systematickou práci s datovým souborem a hledání vzorců a frekvencí slov, obsahu, témat atd. (Payne a Payne 2004: 51-54).

$\mathrm{V}$ našem př́padě se nejprve zaměřím na popis obecnějšího charakteru celého textového korpusu za pomoci použití frekvence nejpoužívanějších výrazů skrze program COOA (podle Hájek 2014), které se objevují v príspěvcích strany na sociální síti Facebook. Následně provedu hlubší kvalitativní rožrazení jednotlivých př́spěvků do kódových kategorií a pokusím se identifikovat jednotlivá mobilizační témata, která získala nadprůměrnou uživatelskou odezvu, s cílem vytvořit základ pro podrobnějšś rámcovou analýzu.

Rámcová analýza (framework analysis) obsahu stojí na přesvědčení, že jednotliví aktéŕi (politici, média, hnutí atd.) interpretují události optikou svého ideologického/hodnotového přesvědčení a tím mohou vědomě či nevědomě zkreslovat realitu. Definici rámce můžeme shrnout za pomoci autorů Gamsona a Modiglianiho (1989: 143), kteří rámec pojímají jako: „ústřední organizující ideu nebo přiběh, který odvíjejícímu se běhu události poskytuje význam (...) Rámec napovídá, v čem daná kontroverze, potažmo jádro tématu, spočívá“. Rámcování je spjato s jednotlivými aktéry, kteři prostřednictvím jednotlivých rámců uchopují danou událost, která následně může, ale nemusí být identifikována jako problém. V tomto rámci se následně začínají rozvíjet narativní zkratky, které mohou např́klad označovat viníky problému, okolnosti vzniku problému, co $\mathrm{k}$ němu přispívá, kdo ho hodlá řešit a jakým zpo̊sobem atd. (Snow a Benford 1992: 139). Snow a Beford (1992) dále rozlišují mezi primárním a sekundárním rámcem. Existuje rozdíl mezi primárním neboli hlavním rámcem (master frame) a sekundárním, kontextově specifickým rámcem (context-specific frame), či tematicky specifickým rámcem (issue-specific frame). Hlavní rámec je konkrétní na rovině ideové či hodnotové a rovněž může zahrnovat i taktické prvky. Tematický rámec označuje jednotlivé krize a kontextový, jak napovídá název, tyto krize zařazuje do širšího prřiběhu. Další teorie hovoří o tř́śložkovém rámovaní skrze diagnostický, prognostický a mobilizační rámec (Caiani, Della Porta a Wagemann 2012: 14). Diagnostický rámec označuje jednotlivé problémy a krize, $\mathrm{v}$ rámci prognostického rámce se navrhují změny a řešení, mobilizační rámec pak pracuje s vyčleněním skupiny od ostatních sociálních skupin, apeluje na společenskou akci a nabízí konkrétní prostředky změny. Cílem rámcové analýzy $\mathrm{v}$ tomto textu tedy bude identifikovat a definovat tematicky specifické a kontextově specifické rámce Dělnické strany sociální spravedlnosti, a pokud to bude možné, definovat hlavní rámec, který tato strana využívá. 
$\mathrm{V}$ závěru této kapitoly věnujme několik slov limitům práce. Při výzkumu v oblasti sociálních médií je základním problémem charakteristika informací a obsahu tvořeného uživateli. Tento obsah může být vysoce nestálý - především ho lze odstranit, revidovat, kopírovat atd. Z tohoto důvodu je nutné pro př́padnou analýzu v určité fázi data „zakonzervovat“, za což však platíme cenu nereflektování dalších změn. Dalším problémem je problematika skrytého obsahu. Jak na webu, tak na sociálních médiích se můžeme setkat s obsahem, který je skrytý před „nezasvěcenými“ uživateli. Budeme-li se držet prostředí Facebooku, jedná se o skryté skupiny a neveřejné profily. $Z$ tohoto důvodu není webové prostř̌edí vhodné $\mathrm{k}$ výzkumu, který by měl dělat závěry o povaze subjektu, jelikož se dá předpokládat, že ten nejextremističtější obsah bude před řadovým uživatelem skryt. To potvrzuje i teorie foot-in-the-door-technique (,technika nohy ve dveřích"), která popisuje metodu náboru nových členů (viz Avukatu, Lupáč 2014). Obecně by se tato teorie dala popsat jako sklon k "normalizaci" informačních výstupů subjektu ve veřejném prostoru, který je vhodnější $\mathrm{k}$ budování popularity a mobilizaci u většího počtu prrípadných podporovatelů. Analýza sociálních médií je tedy spíše vhodná k výzkumu komunikace a schopnosti mobilizace podporovatelů a k monitoringu vazeb mezi subjekty. Informace „propagačního“ charakteru musí být ze své podstaty veřejné, jelikož jsou směrovány na širší veřejnost.

\section{Aktivita DSSS a komunity okolo této strany na Facebooku}

\section{a. Aktivita DSSS}

Co se týká přidávání obsahu, je DSSS je na svém facebookovém profilu velmi aktivní; průměrně vychází, že je na profilu publikováno 1,28 statusů denně, přičemž v roce 2013 a 2014 byla DSSS aktivní 75 \% dnů v roce a v roce 2015 až $82 \%$ dnů (viz tabulka č. 1). Mưžeme tedy říct, že DSSS pravidelnou publikací, která je z hlediska udržitelnosti popularity profilu velmi zásadní, př́spívá k formování komunity okolo svého profilu.

Tabulka č. 1: Data k publikaci statusů na profilu DSSS

\begin{tabular}{|c|c|c|c|c|}
\hline & $\mathbf{2 0 1 3}$ & $\mathbf{2 0 1 4}$ & $\mathbf{2 0 1 5}$ & Celkem \\
\hline $\begin{array}{c}\text { Počet statusů } \\
\text { celkem }\end{array}$ & 483 & 466 & 306 & 1255 \\
\hline $\begin{array}{c}\text { Průměrný počet } \\
\text { statusů na den }\end{array}$ & 1,32 & 1,28 & 1,23 & 1,28 \\
\hline $\begin{array}{c}\text { Procentuální část } \\
\text { aktivních dní } \\
\text { v roce }\end{array}$ & $76 \%$ & $75 \%$ & $82 \%$ & $77 \%$ \\
\hline
\end{tabular}

Zdroj: Autor (zpracováno na základě dat skrze program Netvizz a Excel), n=1255. 
Dále pak můžeme pozorovat určité odchylky od průměru (viz graf č. 1), a to především okolo voleb do Poslanecké sněmovny v záŕí 2013, kdy aktivita DSSS na Facebooku vzrostla. Vůbec nejaktivnější byla DSSS v roce 2013 v den vyhlášení výsledků voleb, které strana reflektovala. V roce 2014 můžeme zaznamenat několik bodů se zvýšenou aktivitou, a to především okolo voleb do Evropského parlamentu a komunálních voleb. Nárazově pak 17. srpna 2014, kdy bylo reflektováno především setkání v Děčíně a petice IVČRN (Islám v České republice nechceme). V roce 2015 byla DSSS nejaktivnější v červnu, červenci a srpnu, a to ve spojitosti s imigrační krizí.

Lze tedy konstatovat, že krom pravidelného přispívání spojeného s komentováním aktuálních zpráv a zveřejňováním př́spěvků z oficiální webové stránky DSSS spojovala strana svoji aktivitu hlavně s volbami a předvolebními kampaněmi (především parlamentními roku 2013), kdy pokaždé aktivita výrazně vzrostla. Výjimkou je v roce 2013 kampaň spojená s protiromskými protesty a rok 2015, který je, co se týká každodenní aktivity, nejvýraznější; zde je patrná dlouhodobější kampaň spojená především s tzv. uprchlickou krizí - na konkrétnější popis se zaměřím $\mathrm{v}$ rámcové analýze.

Dle typu obsahu se z největší části jedná o odkazy na jiné webové stránky (66\%), a to bud' na vlastní stránky DSSS, které jsou tímto způsobem propagovány, nebo weby využívané jako zdroj informace o aktuálním dění, které je následně komentováno. ${ }^{3}$ Druhým nejčastějším typem obsahu jsou fotografie a obrázky $(15 \%)$ a třetím samotný text ve formě statusů $(12 \%)$.

3 Obecně můžeme odkazy rozdělit do dvou kategorií, a to na odkazování za účelem sebeprezentace a odkazování za účelem upozornění na aktuální situaci spojené s postojem strany. Při sebeprezentaci strana odkazuje především na svoji webovou stránku (DSSS.CZ) a web YouTube, kde je strana rovněž aktivní. Pokud se zaměříme na charakter externích zdrojů, jedná se o mainstreamová média, a to především zpravodajské servery zaměřující se aktuální zpravodajství. Na profilu strany se tedy neobjevují odkazy na „alternativni““ zpravodajské servery a zdroje. 
Graf č. 1: Frekvence publikace př́íspěvků DSSS na Facebooku ${ }^{4}$
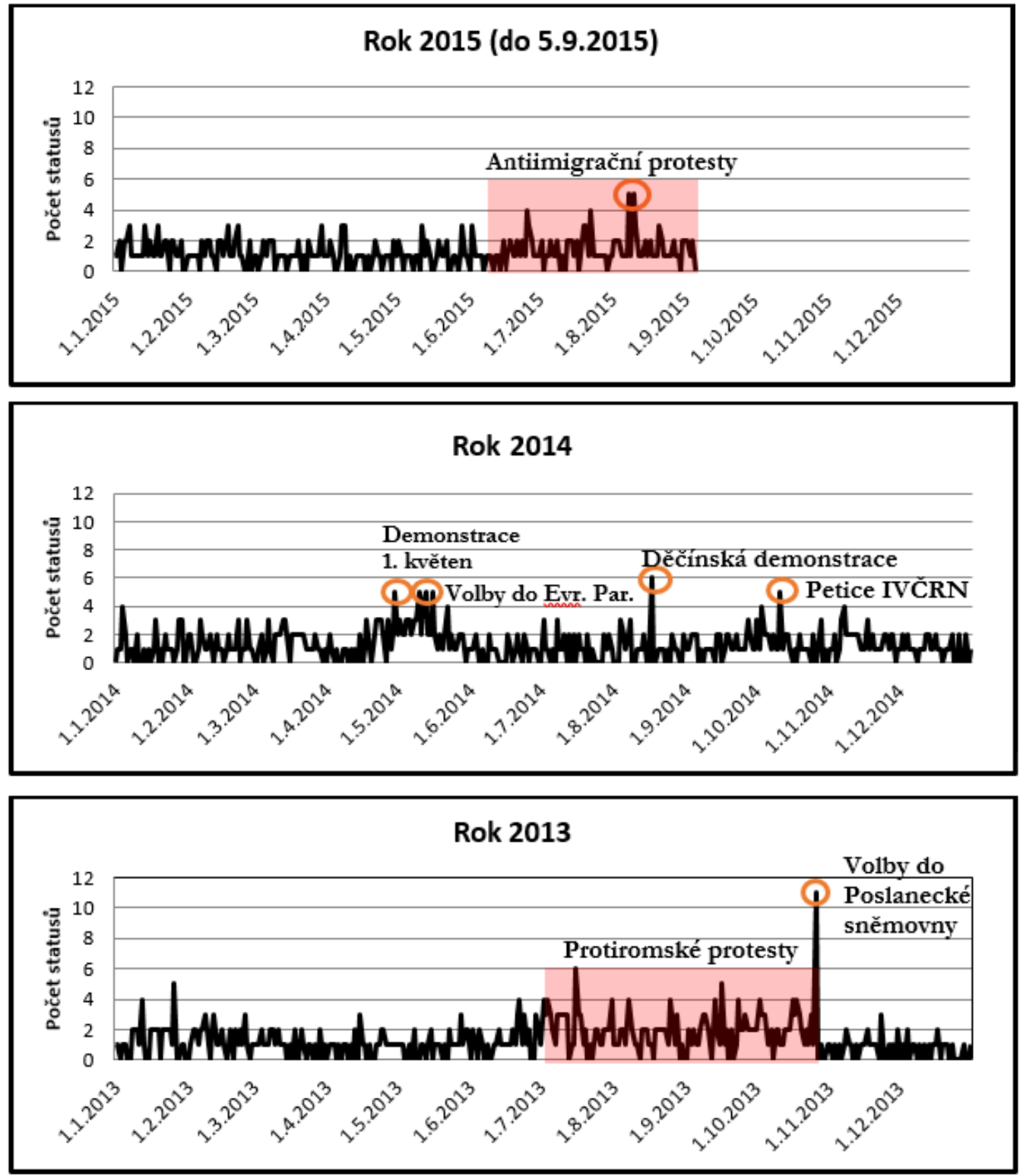

Zdroj: Autor (zpracováno na základě dat skrze program Netvizz a Excel), n=1255.

\section{b. Aktivita uživatelské komunity okolo profilu DSSS}

Přejdeme k definování aktivní uživatelské základny, která je spojena s profilem DSSS. K tomu jsem využil data obsažená v jednotlivých uživatelských interakcích

4 Zvýrazněné části grafu označují delší monotematické úseky, často doprovázené zvýšenou aktivitou. 
(tj. komentářích, sdíleních a „lajcích“) přiřazených k profilům, jež byly alespoň jednou nějakým způsobem na profilu DSSS aktivní (profily, které pouze odebírají príspěvky DSSS a neprovedly žádnou interakci, nejsou zařazeny). Uvedená data mohou být vodítkem $\mathrm{k}$ určení toho, do jaké míry se DSSS povedlo okolo svého profilu vybudovat stabilní komunitu uživatelů. Aktivita podporovatelů na profilu je přitom pro sít’ové šírení informací klíčová.

\section{Graf č. 2: Míra aktivity jednotlivých uživatelů ${ }^{5}$}
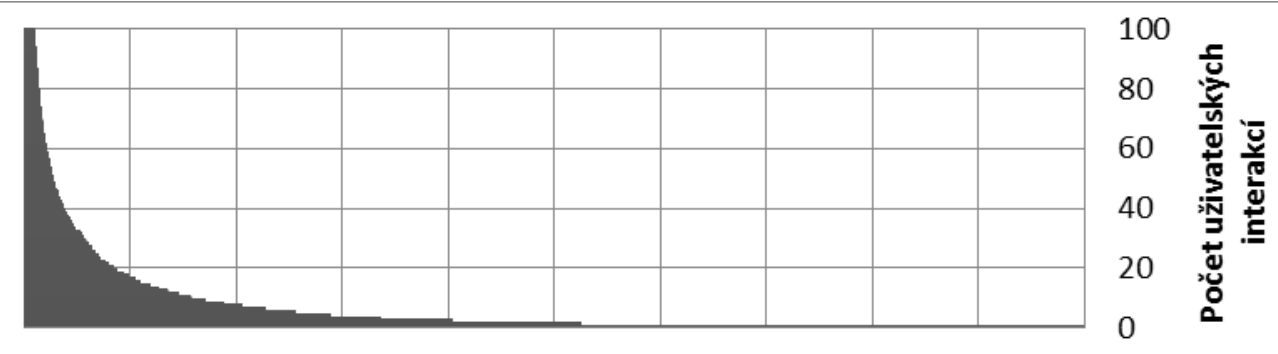

$\begin{array}{lllllllllll}8021 & 7219 & 6417 & 5615 & 4813 & 4011 & 3209 & 2407 & 1605 & 803 & 1\end{array}$

Počet aktivních profilů za sledované období

Zdroj: Autor (zpracováno na základě dat skrze program Netvizz a Excel), n=1255.

Z dat vyplývá, že drtivá většina uživatelů má pouhou jednu interakci a přes $90 \%$ za sledované období nebylo aktivní více než 20krát, což může znamenat, že jsou pouze pasivními odběrateli anebo jejich podpora byla vázána pouze na určitý problém či př́spěvek (viz graf č. 2). Aktivnějšsí část, což odpovídá uživatelské aktivitě, která se pohybuje okolo jedné interakce za měsíc, tvoří méně než $10 \%$ uživatelů. Zhruba $2,75 \%$ uživatelů bylo za sledované období průměrně aktivnější více než dvakrát do měsíce. Můžeme tedy pozorovat vysokou míru pasivity, a pokud by se dalo hovořit o určitém stálém jádru, které je vysoce angažované a pravidelně komentuje, sdílí a „lajkuje“ příspěvky DSSS, tak to tvoří pouze velmi malé procento z celkového počtu odběratelů, spíše se zdá, že uživatelé jsou více než na samotnou DSSS vázaní na aktuální obsah, který DSSS publikuje.

V roce 2013 můžeme pozorovat zvýšenou aktivitu příznivců strany během předvolební kampaně a voleb do Poslanecké sněmovny (viz graf č. 3). Začátkem července 2013 je zřejmá zvýšená aktivita ve spojitosti s protiromskými protesty, a to zejména s demonstrací v Českých Budějovicích. Protiromské př́spěvky vespojitosti s předvolební kampaní koncem ř́jna patří $\mathrm{v}$ tomto období mezi nejpopulámějš́í.

V roce 2014 byla nejpopulárnějším př́spěvkem zpráva popisující „pozitivní diskriminaci cikánů“ týkající se odpuštění dluhu rodinám ze sídliště Chanov, která

${ }^{5}$ Ve sledovaném období bylo na profilu DSSS aktivních 8030 uživatelů (horizontální osa). 
se vyznačuje především vysokým počtem sdílení. Mezi populární příspěvky se rovněž zařadil př́spěvek požadující obnovení trestu smrti ve spojitosti s úmrtím devítileté Elišky Kožnerové, prúspěvky hodnotící volby do obecních zastupitelstev a prríspěvek věnovaný hudební skupině Ortel.

Vůbec největší aktivitu za rok 2015 lze zaznamenat hned začátkem roku, kdy ve spojitosti s útokem 7. ledna 2015 na redakci Charlie Hebdo DSSS zveřejnila sérii př́spěvků týkajících se nebezpečí multikulturalismu a své stanovisko prosazující zákaz a rozpuštění islámských organizací v České republice. Od června pak sklízí největší úspěchy prúspěvky o imigraci a problému se syrskými uprchlíky, což vygradovalo na přelomu června a července, kdy došlo k demonstraci „STOP imigraci!" v Brně.

Graf č. 3: Frekvence aktivity př́źnivců DSSS na Facebooku ${ }^{6}$
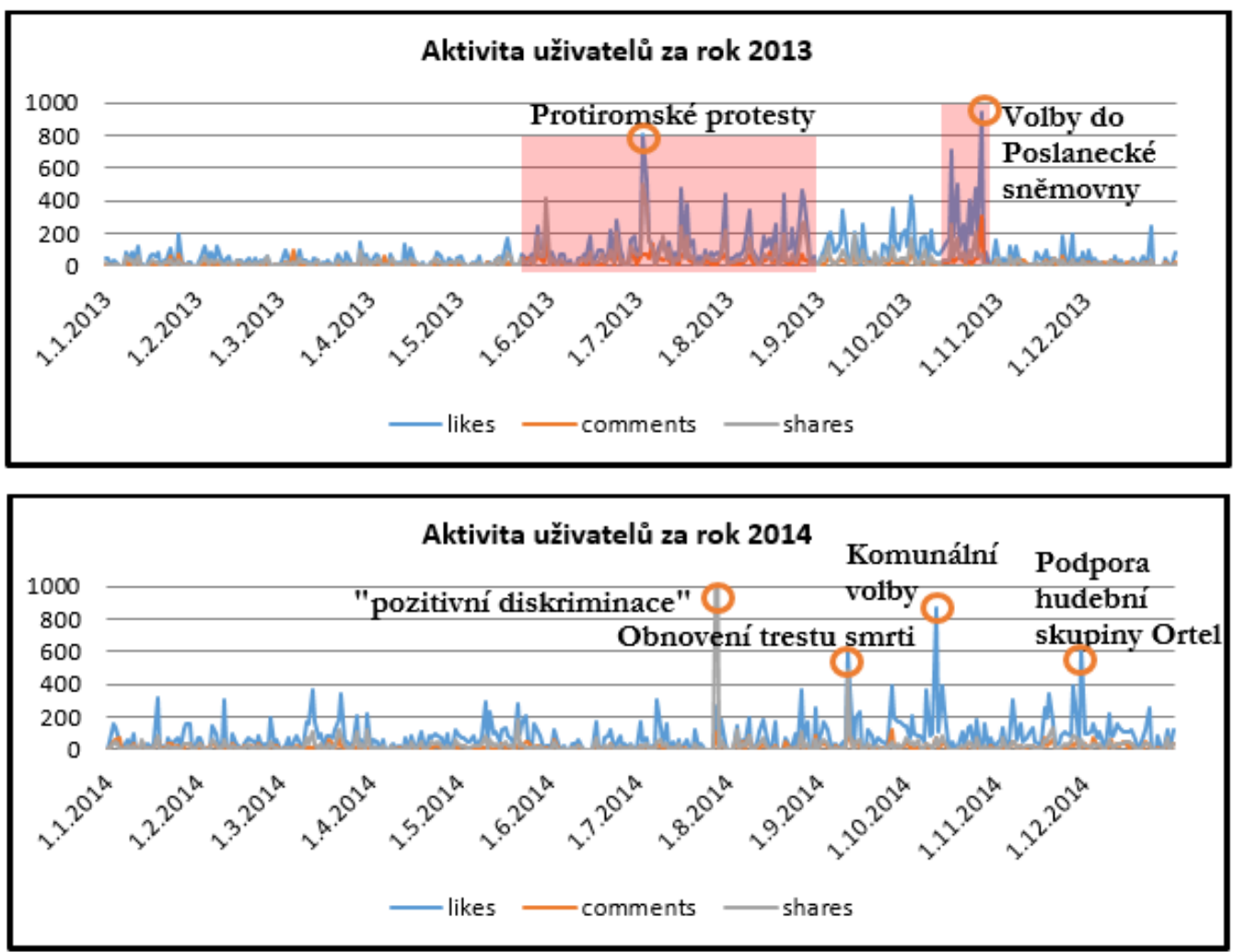

${ }^{6}$ Zvýrazněné části grafu označují delší monotematické úseky/kampaně, často doprovázené zvýšenou aktivitou. 




Zdroj: Autor (zpracováno na základě dat skrze program Netvizz a Excel), n=1255.

Shrneme-li výsledky základní analýzy dat, můžeme konstatovat, že strana je na svém profilu aktivní a pravidelně přidává nový obsah. Nejaktivněji přitom vystupuje během voleb a předvolebních kampaní; v roce 2015 aktivita strany vzrostla ve spojitosti s uprchlickou krizí. Komunikace strany se pak omezuje na vkládání prŕíspěvků a v diskuzích se nijak neangažuje.

Rovněž jsem se zabýval identifikací tzv. tvrdého jádra podporovatelů této strany na Facebooku a v tomto ohledu jsem zjistil, že přestože si strana udržuje stabilní uživatelskou aktivitu na profilu, je počet pravidelných příznivců strany, kteří by na profilu nějakým zpo̊sobem interagovali a pomáhali tak šírit informace $\mathrm{k}$ dalším potencionálním př́żnivcům, marginální. Podporovatelé této strany $\mathrm{v}$ drtivé většině př́padů reagovali ve sledovaném období pouze príležitostně a můžeme tedy předpokládat, že jejich podpora je spíše tematická a vázána na konkrétní událost. Strana tedy nemá na svém profilu vybodovanou početnější aktivní komunitu. Tuto domněnku potvrzují i skokové nárůsty aktivity na profilu, které lze v jednotlivých letech pozorovat. V roce 2013 byla nejvíce upřednostňována témata s protiromským naladěním a volby do Poslanecké sněmovny. Rok 2014 byl tematicky pestřejší a mezi nejúspěšnější př́spěvky patřila krom těch protiromských výzva k obnovení trestu smrti, komunální volby a podpora skupiny Ortel. V poslední sledované části roku 2015 byly nejlépe hodnoceny př́spěvky spojené s antiimigračním a antiislámským tématem.

\section{Souhrnná obsahová analýza a identifikace mobilizačních témat}

Datový korpus nejprve podrobím analýze nejčastěji používaných výrazů a následně se zaměrím na jednotlivé posty (příspěvky), které budu s pomocí induktivního kódování zařazovat do kategorií zahrnujících mobilizační témata, jež 
strana v daném období artikulovala a jež si současně získala nadprůměrnou uživatelskou odezvu.

Mezi nejčastěji používané výrazy, které se objevují v textech publikovaných DSSS na Facebooku ve sledovaném období, patřila slova jako „sociální“, „české“, „republiky“, „náméstí, „Praze“, „strana“, „země“, „občany“ - tedy slova, která mají spíše neutrální charakter. Pak si můžeme všímat slov jako je „stop“ a „proti“, které slouži k vymezení se vưči něčemu, a dále pak slov týkajících se již konkrétního problému, proti kterému se DSSS vymezuje, a to „imigrace“ a ,islamizace".

Zaměříme-li se na slovní spojení „proti...“ a „stop...“, tak nejvýraznější kategorií je imigrace, která je spojována s islamizací a prezentována jako hrozba. $\mathrm{Na}$ to je navázán „zločinný Brusel“, tedy instituce Evropské Unie, a „pseudohumanistická spodina“, kterou jsou označování zastánci integrační politiky EU a lidských práv. Dále se DSSS vymezuje proti „zkorumpované vládě“, „parazitujícím nepřizpůsobivým“ a jejich kriminalitě a „uživatelům a dealerům drog“. DSSS se velmi radikálně vymezuje vůči imigraci, př́́davná jména u slova „...imigrantư“ nám mohou nastínit proč. Ve vybraných př́spěvcích se o imigrantech hovoří jako o „nelegálních“, „nepotřebných“ a „agresivních“, přičemž zmiňováni jsou často na základě toho, že byli zadrženi bezpečnostními složkami.

Graf č. 4: Obsahová analýza mobilizačních témat za rok 2013

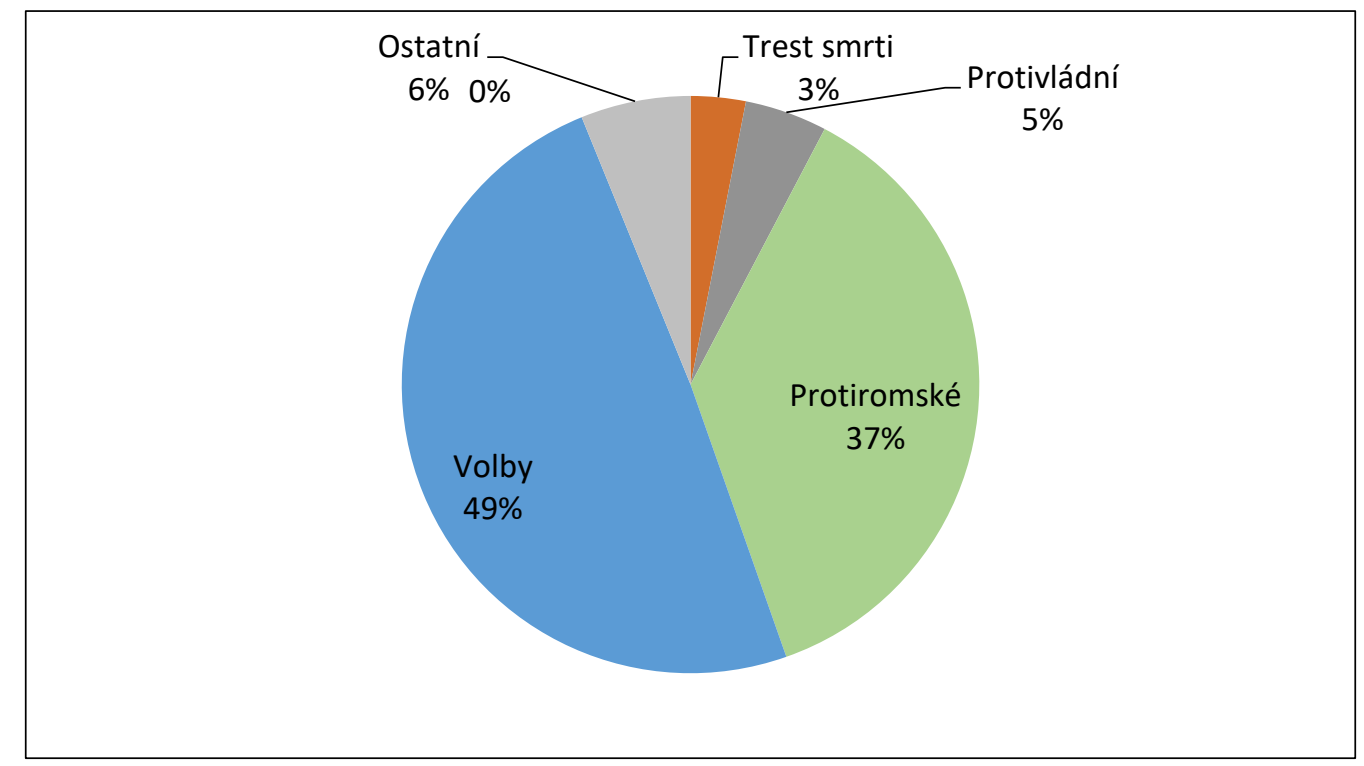

Zdroj: Autor na základě sesbíraných dat. 
Rok 2013 (viz graf č. 4) se vyznačuje dvěma hlavními tématy, která se navzájem prostupují, a to protiromskými tématy (37\% příspěvků) a předčasnými volbami do Poslanecké sněmovny (49\%). Podporovatelé strany v rámci protiromských témat nejvíce reflektovali protesty v Duchcově a Českých Budějovicích; rovněž došlo $\mathrm{k}$ silné reakci $\mathrm{v}$ př́ípadě výstavy návrhů českoromských vlajek. Předčasné volby do Poslanecké sněmovny a volební kampaň pak měly ohlas u podporovatelů, kteří reflektovali především předvolební hesla zaměřená na „cikánský rasismus“, neschopné polistopadové vlády, vystoupení z EU, sociální programy pro „ty, co si to zaslouži“ atd. Mezi další témata, která vzbudila v roce 2013 nadprůměrné reakce, patřila především otázka zavedení trestu smrti, ale i zákazu kouření na veřejných místech. $\mathrm{V}$ tomto roce můžeme pozorovat dvě ucelené monotematické mobilizační kampaně: v první polovině roku protiromsky zaměřenou kampaň a ve druhé polovině předvolební kampaň.

Na rozdíl od roku 2013 již není rok 2014 do takové míry monotematický a mobilizační témata, která př́innivci strany nadprůměrně reflektovali, mají pestřejší charakter (viz graf č. 5). To může být způsobeno volebním neúspěchem, kterým skončily parlamentní volby $\mathrm{v}$ předešlém roce a který stranu prriměl $\mathrm{k}$ hledání nových mobilizačních témat. Nutno dodat, že takové téma se našlo v protimuslimském zaměření, které má největší podíl na nadprůměrně reflektovaných př́spěvcích toho roku $(18 \%){ }^{7}$ Nechybí ovšem ani protiromská témata $(12 \%)$, u kterých ale pozorujeme silný pokles oproti minulému roku. To může nasvědčovat vyčerpání tohoto tématu jak ze strany DSSS, tak ze strany podporovatelů, kteři na tuto problematiku začali být méně citliví. Dále mezi nejvíce reflektovaná témata patř́ téma voleb do Evropského parlamentu spojené především s kampaní proti EU. Musíme rovněž upozornit na stoupající zájem o problematiku imigrace $(7 \%)$. Mezi další témata, která se objevila v roce 2014, patří zavedení trestu smrti, protest proti humanitární pomoci do zemí třetího světa a podpora hudební skupiny Ortel. Na rozdíl od roku 2013 v tomto roce neprobíhaly dlouhodobé monotematické kampaně, což opět nasvědčuje fragmentaci mobilizačních témat a snaze nalézt nové nosné téma.

Rok 2015 (viz graf č. 6) s přehledem patřil tématu imigrace (45\%). Př́źnivci strany toto téma reflektovali $\mathrm{v}$ daném roce nejčastěji, ale $\mathrm{z}$ dat vyplývá, že i za celé sledované období získaly antiimigrační prríspěvky roku 2015 největší uživatelskou odezvu. DSSS tedy ve spojitosti s „uprchlickou krizi“ našla nosné téma s největším mobilizačním potenciálem za poslední tři roky. Své prřiznivce si však našly i stálé tematické oblasti (protiromské, proti EU) a došlo k posílení kritiky vlády a EU, a to právě ve spojitosti s imigrací. Mưžeme vypozorovat, že protiimigrační kampaň byla vedena s různou intenzitou po celý rok a od druhé poloviny roku je př́tomno silné protivládní zaměření.

\footnotetext{
${ }^{7}$ Protimuslimská rétoriku byla v roce 2014 mířena na islám a muslimy v obecné rovině. Později se mobilizační téma zdůrazňující nebezpečí islámu překryla s tzv. „imigrační krizí“ v roce 2015.
} 
Graf č. 5: Obsahová analýza mobilizačních témat za rok 2014



Zdroj: Autor na základě sesbíraných dat.

Graf č. 6: Obsahová analýza mobilizačních témat za rok 2015

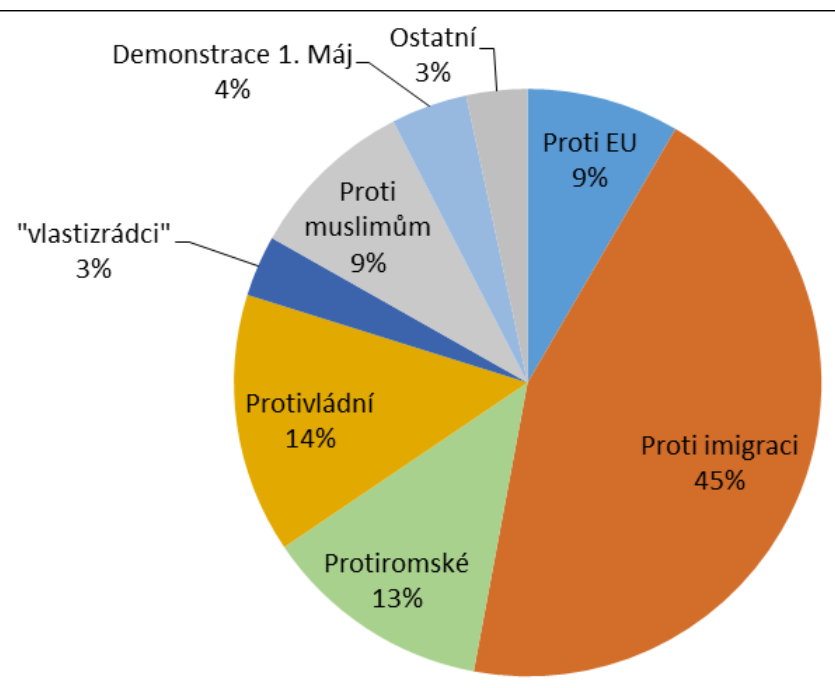

Zdroj: Autor na základě sesbíraných dat. 
Graf č. 7: Nejúspěšnější mobilizační témata Dělnické strany sociální spravedlnosti dle počtu uživatelských interakcí



Zdroj: Autor (zpracováno na základě dat skrze program Excel), n=230.

Co se týká vývoje, největší změnu zaznamenalo mobilizační téma zaměřené na protiromské nálady, které dominovalo roku 2013 a v následujících letech již bylo př́znivci strany reflektováno spíše okrajově. To však není způsobeno změnou postoje $\mathrm{k}$ této problematice, ale jejím zastíněním tématem imigrace a antimuslimských nálad, které se ve větší míře začaly objevovat právě v roce 2014 a v roce 2015 naprosto dominovaly mobilizačním tématům DSSS (viz graf č. 7).

\section{Rámcová analýza mobilizačních témat}

Pokud budeme hlouběji analyzovat, co má většina př́spěvků s nadprůměrnou reakcí společné, tak je to negativní naladění, kdy se DSSS a její př́źnivci vůči něčemu vymezují nebo se staví do opozice. Mobilizace př́ínivců DSSS je tedy založena na principu negace a vymezení se, a to at' proti něčemu či někomu. Obecně jsou jednotlivá témata stavěna na základě toho, že současný stav škodí občanům ČR, respektive národu. Následně jsou označeni viníci, kteří bud’to př́mo způsobují daný problém, podílejí se na něm, nebo ho nejsou ochotní řešit. Celkový boj proti „vlastizrádcům“ je následně zasazen do širšího kontextu určitého hodnotového rámce. Protiromská témata jsou artikulována na základě pocitu nespravedlnosti, témata protivládní a proti EU na základě ztráty suverenity, korupce a neefektivnosti. Téma islámu a imigrace je vystavěno stejně jako protiromské téma na pocitu nespravedlnosti a je navíc doplněné o rámec útoku na evropskou identitu a hodnoty (viz shrnutí celé analýzy v tabulce č. 2 [v př́loze]).

\section{a. Protiromská mobilizační témata}

Protiromská tématika se dle dat ukázala v oblasti mobilizace příznivců strany jako jedna z nejsilnějších. K nejsilnější odezvě v rámci protiromských témat došlo 
začátkem června roku 2013, kdy se na profilu DSSS projevil zájem prŕíznivců o kauzu, při níž došlo v Duchcově k napadení manželského páru skupinou Romů. Následně byla přes sociální média vyjadřována podpora občanům Duchcova $\mathrm{s}$ př́slibem uskutečnění demonstrace $\mathrm{v}$ režii DSSS. Demonstrace, která byly naplánovaná na 22. června, byla propagována skrze profil strany a vyvolala nadprůměrný zájem př́znivců strany. Jako mobilizační spouštěče zde měly fungovat již výše zmíněna kauza napadení a dále pak obecnější emotivní slogany, jako je např́ílad: „Mít strach poslat děti do školy není normální“. $\mathrm{Na}$ samotné demonstraci vystoupil předseda strany Tomáš Vandas a značná část jeho projevu byla zaměřena protivládně. Za problémy jsou dle Vandase odpovědní vláda a podpora vlády „cikánským spolkưm“ a samotní Romové, kteří zneužívají sociální dávky a „parazitují na společnosti“. Stejného ohlasu se dostalo od př́znivců strany i budějovickým protestům, které přestože byly protiromské, měly ještě mnohem silnější protivládní apel. To se projevilo i při mobilizaci skrze sociální média, a to výzvami „Kde mlčí stát, tam promluví ulice!“" nebo výzvou „Egypt, náš vzor!“ odkazující na protivládní nepokoje v Egyptě. K další silné odezvě u príznivců strany, která navazovala na předchozí protesty, došlo v př́padě výstavy česko-romské vlajky. DSSS na svém profilu uveřejnila 18. července 2013 príspěvek s článkem „Hanobení státní vlajky cikánskými symboly je trestný čin“ a následovalo několik nadprůměrně hodnocených pŕíspěvků s touto tématikou. DSSS následně informovala o tom, že výstava návrhů česko-romských vlajek byla poškozena neznámým pachatelem. Linkou, která prostupuje všemi kauzami, je „pozitivní diskriminace“, kterou DSSS prezentuje jako zvýhodňování Romů státem na úkor majority a takto vzniklá nespravedlnost.

Z obsahové analýzy vyšlo, že posty s nadprůměrným mobilizačním potenciálem se stavěly do opozice vưči „parazitujícím nepřizpůsobivým“, „nepořádku a za účelem ochrany slušných lidi“" a „narůstající kriminalitě ze strany nepřizpůsobivých občanů“. Obecně jsou tedy Romové líčeni jako „rozmazlení cikáni“", kteři dostávají od státu něco, na co nemají nárok, a to na úkor „slušných“ občanů. Navíc dochází ke generalizaci, která se projevuje v př́padech kauz napadení - za viníka napadení je označována romská minorita jako celek. $\mathrm{Na}$ vině je pak stát a vláda, která dovoluje „cikánům“, „cikánským spolkům“ a „pseudohumanistické spodině“ profitovat z veřejných rozpočtů. Romové se tak stávají zástupným problémem pro kritiku vládní politiky, přičemž problém není v sociální podpoře jako takové (z důvodu zastávání odlišných ekonomických principů), ale v tom, že se dostává k těm, kteří si ji dle DSSS nezaslouží.

Role sociálních médií je líčena jako prostředek poskytující alternativní zdroj informací, který obchází klasická média, jež jsou k DSSS a jí prezentovaným tématům neobjektivní. Zajímavé je, že na svém profilu DSSS čerpá informace právě $z$ těchto mainstreamových médií. Sice jsou tyto př́spěvky rámovány, aby zapadaly do postojů strany, ale neprobíhá žádná kritická reflexe založená právě na 
artikulaci neobjektivity mainstreamových médií, pokud se nejedná o články př́mo kritizující stranu.

Další zajímavostí je, že DSSS a její příznivci na Facebooku se staví proti jakékoliv snaze státu integrovat romskou menšinu. Mezi nadprůměrně ohodnocené prríspěvky se dostaly ty, které kritizovaly vynakládaní prostředků např́klad na školení policistů pro práci v sociálně vyloučených lokalitách; pravidelně jsou kritizovány i neziskové organizace $\mathrm{v}$ těchto lokalitách působící. Např́klad:

„DSSS: A zase se bude integrovat, jako posledních několik desetiletí, budou se vyhazovat peníze, dotovat cikánské rasistické spolky jako ROMEA, zvýhodňovat na úkor ostatních, učit romsky, a vše budou platit daňoví poplatníci, kteři už prostřednictvím vládních korupčníků do tohoto etnika nacpali miliardy. Ale lidem to nevadí, oni je přece zvolí znovu..."

„...Ombudsmanka Šabatová je produktem kolaborantské havlovské kliky a svými názory přesně doplňuje svého manžela, ortodoxního marxistu Uhla. Poslanecká sněmovna by ji měla okamžitě odvolat, protože to, co předvádí v této funkci, je naprostá degradace původního poslání instituce ombudsmana. Pokud chce tedy dělat ochránkyni cikánům, tak ne za státní peníze. At’ jí platí Romea a spol.“

Př́znivci strany jsou následně mobilizování na základě obecných, deklarativních prohlášení typu:

„Duchcov se stal městem, kde slušní lidé neměli zastání a byli terorizováni nepřizpůsobivými živly. Je potřeba s tím něco konečně udělat!"“

„DSSS: Postupoval by mostecký magistrát stejně, pokud by se nejednalo o cikány? STOP pozitivní diskriminaci, požadujeme platnost zákonů pro každého, bez rozdílu barvy pleti!“

Strana tedy rámuje protiromská témata jako ochranu slušných lidí, kteř́ jsou nespravedlivě poškozování upřednostňováním Romů ze strany státu. Vláda se tak stává terčem kritiky a je označována jako viník problému, přičemž jako řešení se nabízí výběr zástupců z řad DSSS ve volbách. Za hlavní rámec $\mathrm{v}$ tomto problému můžeme považovat snahu o odbourání „nespravedlností“, která je páchána na občanech „bílé barvy kůžěe.

Posledním poznatkem, který musíme zmínit v rámci protiromských témat, je výrazná citlivost př́znivců strany na státní symboliku, která se prezentuje do kauzy česko-romské vlajky. To upozorňuje jak na silný nacionální prvek, který je u prŕżnivců strany př́tomen, tak i na silnou reakci, kterou vyvolalo převzetí národního symbolu „cikány“.

\section{b. Protivládní témata, témata proti EU a volby}

Protivládní zaměření DSSS se objevuje $\mathrm{v}$ každém mobilizačním okruhu a u podporovatelů má vysokou odezvu. Vláda je často označovaná jako 
„zkorumpovaní korytáříc, „zloději“ a rovněž je DSSS prezentuje jako príićinu problémů „pozitivní diskriminace cikánů“, imigrace a ztráty suverenity země ve prospěch EU. Nutno podotknout, že kritika často překračuje pouze aktuální vládní sestavu, ale cílí na celé stranické spektrum a systém obecně:

„Zkorumpovaná žvanírna se rozpustila, budou předčasné volby. DSSS je připravena ucházet se o důvěru voličǔ!“

„Předseda DSSS Tomáš Vandas: Další výsměch občanům. Důchodcům přidáme (možná) 200 korun, mladým rodinám s dětmi raději nic, ale poslanecké platy se budou zvedat "jen" o tisíce... Řešením je vypráskat tu nenažranou bandu, ale to bychom nesměli být v České republice, kde budeme jen brblat u piva či televizního seriálu, anebo vystavovat červenou kartu.“

Kritika polistopadového politického systému se tak stala základním kamenem politiky DSSS a jelikož se strana nikdy nedostala do Parlamentu a nebyla zapojena do rozhodovacího procesu, může označovat parlamentární strany za príćinu v tu chvíli aktuálních problémů. Tato kritika je často doplněna o výzvu k volbě DSSS v nadcházejících volbách. Vláda je líčena jako problém sám o sobě, přičemž důraz je kladen především na korupci a neefektivitu.

Ve sledovaném období můžeme zaznamenat zostřování rétoriky a zvyšující se popularitu protivládních výroků, a to zejména ve spojitosti s imigrací a tzv. „uprchlickou krizi“:

„Zatímco mad’arská vláda našla peníze na stavbu plotu proti imigrantům s cílem chránit svoji zemi, česká vláda už vyčleňuje peníze na stavbu nových uprchlických zařízení, které jen $\mathrm{v}$ př́štím roce mají spolknout navíc 1,1, miliardy korun...české nemocné děti či seniơ̌i mají smůlu. STOP vlastizrádcům!““

„DSSS: Opravdu chceme jen nečinně přihlížet, až se to bude dít i v České republice? Premiér Sobotka se v Bruselu "podělal" a slíbil dobrovolné přijímání imigrantů. A ještě to označuje za triumf! Vládne nám vlastizrádná sebranka, myslící jen na svoje koryta! Pryč s takovým režimem!“

Začaly se častěji používat výrazy týkající se vlastizrady a neurčité výhružky typu:

„Vládní sebranka se zatím směje občanům a dělá si, co se jí zlíbí. Přijde však doba, kdy jim úsměvy ztuhnou...“

Nechybí však i výhružky, které jsou již konkretizovány a za hranicí respektování demokratického politického rámce:

„Za rozhodnutí vlády, přijmout dobrovolně(!) 1500 imigrantů, si členové vlády zaslouží odměnu, která ale rozhodně sladká nebude..."

Zvyšují se tedy tendence $\mathrm{k}$ zostřování rétoriky proti vládě, které mají ohlas u prŕżnivcú strany, a to z velké části ve spojitosti s protiimigračními protesty. 
Tento trend se promítl i do kritiky EU, která je dle DSSS rovněž odpovědná za současnou ,imigrantskou krizi“:

„DSSS PROTI KVÓTÁM: Důrazně odmítáme přerozdělování a řízené přesuny imigrantů na území EU! Jsme proti přítomnosti uprchlíků z Afriky a Blízkého východu na území České republiky. Tento šílený monstrplán s nuceným přesunem desítek a stovek tisíc osob jiných kultur po Evropě prípomíná organizované přesuny židů během II. světové války. Místo holocaustu nás čeká autogenocida evropských národů! Postavme se na odpor proti zločinnému Bruselu!“

„Evropská komise = Islámský stát. Pokud se tomuto teroru nebudeme bránit, naše evropská civilizace skončí jako trosky v Palmýře..."

„DSSS požaduje obnovení suverenity ČR. To je však možné jen v případě, že opustíme Evropskou unii, která se ukázala v souvislosti se současnou imigrantskou krizí jako totálně neschopná. Požadujeme proto referendum o vystoupení ČR z bruselského byrokratického molochu. STOP diktatuře EU“

Mobilizační téma stavěné na odporu vůči EU má však delší tradici. Vrchol kritiky EU můžeme ve sledovaném období vnímat v první polovině roku 2014 ve spojení s volbami do Evropského parlamentu. K této príležitosti DSSS prezentovala na Facebooku svou kampaň „Pryč z krize = pryč z EU“, která prosazovala vystoupení z EU. Pokud se zaměříme na výsledky obsahové analýzy, můžeme konstatovat, že legislativa EU je prezentována jako „diktatura“ vedená ze „zločinného Bruselu“. Krom kritiky ztráty suverenity, kdy je EU stavěna do pozice aktéra, který diktuje pravidla a jde proti národním zájmům země, můžeme vnímat i silnou symbolickou stránku, která má ohlas u př́znivců strany. Jedná se především o vlajku a měnu, jež je uváděna jako symbol měnové a ekonomické suverenity země, ale můžeme zde vidět i přesah v ochraně tradičního symbolu národa:

„Vlajka EU je pro nás bezcenným hadrem, nebot’ my, vlastenci, uznáváme pouze vlajku národní, českou.“

"Budoucnost má česká koruna, ne euro. Bojujte s námi za naši národní suverenitu."

Protestní pálení vlajky EU nebo její zobrazování jako toaletního papíru a další protesty ve stejném duchu pak tvoří silný mobilizační prvek. Posledním terčem kritiky je tzv. „pseudohumanistická spodina“, do které jsou zařazeni jednotlivci i skupiny, kteří se dostávají do názorového střetu s DSSS v otázkách integrování menšin, lidských práv, integrace EU a podobně.

Pokud bychom měli tedy nějakým způsobem shrnout rámec protivládních témat, mưžeme konstatovat, že tento rámec je prítomen soustavně, a to ve dvou

${ }^{8}$ Dostupné z https://www.facebook.com/Pry\%C4\%8D-z-krize-pry\%C4\%8D-z-EU-4396240261 $20835 /$. 
rovinách. Stabilně se upozorňuje na neefektivitu a zkorumpovanost establishmentu a z hlediska času se mění pouze to, do jakého kontextu se kritika vlády a parlamentních stran zasazuje. V roce 2013 byla kritika spojena především s protiromskými protesty, $\mathrm{v}$ roce 2014 kritika vlády v podstatě kopíruje jednotlivá další témata a objevuje se ve spojení jak s protiromskou tématikou, tak volbami do Evropského parlamentu, postoji $\mathrm{k}$ islámu, humanitární pomoci do zemí třetího světa atd. Roku 2015, jak už bylo několikrát řečeno výše, dominovala kritika vlády v kontextu imigrační politiky.

Poslední téma, které zde zmíníme, je téma voleb. Ty jsou prezentovány jako nástroj možné změny a strana věnovala značnou část aktivit tomu, aby mobilizovala voliče $\mathrm{k}$ účasti ve volbách. Volby jako nástroj změny však strana uznává pouze z hlediska toho, že by se sama dostala do Parlamentu. Př́spěvky, které se vztahují přímo $\mathrm{k}$ volbám, pak většinou obsahují fotografie kandidátů často doplněné o vyhrocená hesla odkazující na jednotlivé mobilizační okruhy.

\section{c. Témata protiimigrační (proti muslimuim a islámu)}

Mobilizace na základě protiimigračního tématu (ve spojení s negativním postojem $\mathrm{k}$ islámu a muslimům obecně) se stala $\mathrm{v}$ uplynulém roce nejdominantnějším tématem a ve sledovaném období vzbudila nejvyšší ohlas u př́iznivců strany na Facebooku. Jak tedy DSSS prezentuje „imigrační krizi“ a co považuje za problém? Můžeme konstatovat, že základ tohoto tématu vychází ze stejných předpokladů jako protiromská mobilizace. Muslimové jsou stejně jako Romové stavěni do pozice někoho, kdo si dělá nárok na něco, co mu nenáleží, a tím vzniká nespravedlnost vưči majoritě. Mưžeme se setkat s názorem, že: „...sebevědomí muslimů je prrímo úměrné debilitě Evropanů.“, což naráží stejně jako v př́padě protiromské problematiky na kritiku „ústupků“ vlády směrem k muslimům. Strana imigranty označuje jako „hordy“, „nevítané parazity“, „imigrantský plevel“ mající zájem na zneužívání sociálního systému státu (nechybí ani na českých sociálních médiích již zprofanovaná fráze o sbírání víček).

Krom této roviny, která je téměř identická s kritikou Romů, můžeme dále pak spatřovat novou rovinu, a to hodnotovou, která upozorňuje na odlišnosti mezi islámem a západní společností - strana upozorňuje na zachování evropských hodnot a zabránění „genocidě národa“. Imigrace a muslimská komunita v Evropě jsou dávány do spojitosti steroristickými útoky a strana uplatňuje princip kolektivní viny. Tomu nasvědčuje reakce po útocích na Charlie Hebdo, kdy strana požadovala rozpuštění českých islámských organizací (Ústředí muslimských obcí, Muslimské unie). Krom muslimů strana cílí stejně jako v romské problematice na vládu, EU, „pseudohumanistickou spodinu“, „multi kulti kolaboranty“ a „vlastizrádce“, kteří sympatizují s uprchlíky nebo muslimy obecně. Objevily se dokonce požadavky na ,vyvození trestní odpovědnosti vůči všem osobám, které prosazují př́liv imigrantů na naše území". Obecně můžeme říci, že agresivita 
rétoriky je ve spojitosti s tímto tématem mnohem vyšší než u jiných mobilizačních témat a výjimkou nejsou výhružky a otevřeně xenofobní postoje, které strana projevuje mnohem otevřeněji než u jiných témat, a až hysterický naléhavý apel:

„Pokud se napříc národy nepostavíme tomuto černému moru na odpor, skončíme my a naše děti jako otroci Islámského státu!“

Jako řešení pak DSSS navrhuje „nekompromisní postup vưči všem, kteří chtějí nelegálně vstoupit na evropskou pưdu. Společně nasadit armády, potápět lodě, zachráněné $\mathrm{z}$ moře vracet do Afriky (...) odstavit od moci kolaboranty v Bruselu.“ V př́ípadě uprchlíků, kteří jsou již přítomní v Evropě, pak požaduje jejich vyhoštění.

Pokud bychom měli rámování tohoto tématu shrnout, můžeme konstatovat, že do velké míry nahradilo již tematicky vyčerpanější protiromskou mobilizaci, přičemž základní argumentační linie zůstala z velké části stejná. Kontextuální rámec se nezměnil; strana usiluje o zvolení do zastupitelských úřadů, kde by mohla prosazovat „spravedlivý“ režim v rámci imigračního tématu, doplněný o národnostní prvek charakterizovaný sloganem „Cizinec není našinec“. V rámci mobilizačních technik jsou prezentovány především protesty a demonstrace s již zmíněnou tvrdší rétorikou a výhružkami směrovanými na názorové oponenty a „vlastizrádce“.

\section{Zhodnocení výsledků analýzy}

V př́padové studii jsme se snažili nalézt odpověd’ na otázku „Jaké témata DSSS jsou úspěšná při mobilizaci př́znivců strany?“ $\mathrm{Na}$ základě výsledků analýzy (viz schéma č. 1) můžeme konstatovat, že DSSS skutečně využívá svůj facebookový profil velmi aktivně a pravidelně, a to jak k sebeprezentaci, tak i krámování jednotlivých mobilizačních témat.

Přestože se straně daří udržovat stabilní míru uživatelské aktivity, je překvapivé, že počet pravidelných prŕznivců strany, kteří by na profilu určitým způsobem pravidelně interagovali a pomáhali tak šírít informace $\mathrm{k}$ dalším potencionálním prŕźnivcům, je marginální. Strana nedisponuje na Facebooku větším množstvím př́znivců, které bychom mohli zařadit do aktivnějšího jádra. To poukazuje spíše na silnější tematické zaměření prríznivců, než na př́zeň orientovanou obecněji na stranu jako takovou.

V roce 2013 byla na Facebooku strany nejvíce reflektována témata s protiromským naladěním a volby do Poslanecké sněmovny. Rok 2014 byl tematicky pestřejší a mezi nejreflektovanější prríspěvky krom protiromských patřila výzva k obnovení trestu smrti, komunální volby a podpora skupiny Ortel. Ve sledované části roku 2015 byla největší aktivita př́znivců strany spojena s antiimigrační a antiislámskou tematikou. Konkrétně jsou tedy nejúspěšnějšími mobilizačními tématy téma protiimigrační, potažmo zaměřené proti muslimům, 
téma mobilizace proti establishmentu, téma mobilizace proti EU a téma protiromské.

\section{Schéma č. 1: Mobilizační témata DSSS a jejich rámování}

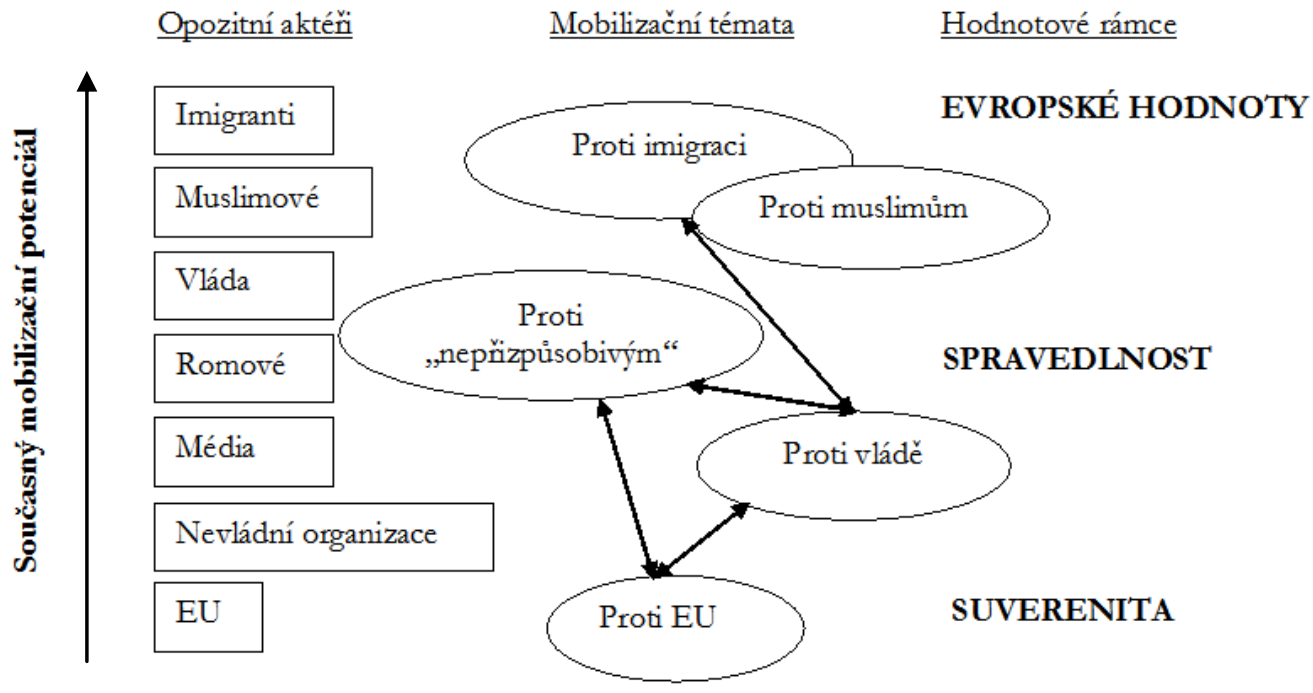

Zdroj: Autor na základě sesbíraných dat.

Co se týká vývoje, největší změnu zaznamenalo mobilizační téma zaměřené na protiromské nálady, které dominovalo roku 2013 a v následujících letech již bylo prríznivci strany reflektováno spíše okrajově, což však není způsobeno změnou postoje $\mathrm{k}$ této problematice, ale jejím zastíněním tématem imigrace a antimuslimských nálad, které se ve větší míře začaly objevovat právě v roce 2014 a v roce 2015 naprosto dominovaly mobilizačním tématům DSSS. Změny $\mathrm{v}$ rozložení těchto témat můžeme vnímat i z pohledu samotné strany, která po neúspěšných volbách 2013 začala hledat náhradu a úspěšnější programatiku a díky aktuální situaci a kontextu „uprchlické krize“ takovéto téma našla v odporu $\mathrm{k}$ imigraci a islámu.

Všechny rozebrané rámce, která strana používá, jsou velmi přímočaré a obsahují vždy jasně označený problém, jeho viníka a řešení. Romové a imigranti sdílejí velkou část rámování a z pohledu DSSS jsou označováni jako tzv. „paraziti“, kteři zneužívají prostř̌edky státu, které si nezaslouží a měly by sloučit pouze občanům, respektive etnickým Čechům. U imigrantů a potažmo muslimů obecně je navíc rámec doplněn o hodnotovou složku, kdy je dáván islám do opozice vưči západním hodnotám. Důkazem mají být teroristické útoky, které spojovány jak s imigrací, tak s muslimskou komunitou obecně. Právě pozice 
menšin, kterým se krajní pravice snaží oponovat $\mathrm{v}$ případě rozšiřování práv i uplatňování práv stávajících, je v př́padě střední a východní a střední Evropy do velké míry spojena s europeizací, mimo jiné skrze členství v EU (Bustikova 2015: 66). To se rovněž odráží i v námi analyzovaných mobilizačních tématech a to, jak prímo na cílení na Romské etnikum, tak na jeho „zastánce“ neziskové organizace, EU i jednotlivé osobnosti; podobný scénář se následně přenesl do problematiky imigrace. Kritika vlády a EU pak prostupuje všemi rámci, přičemž vláda je označována (společně s dalšími aktéry) za př́ćinu současného stavu.

Prvoliniová řešení, která strana nabízí, jsou pak velmi rázná a zjednodušená. V kontextuální rovině strana usiluje o voličské hlasy, které by mohla využít $\mathrm{k}$ napravení nespravedlností páchaných na občanech CR a k obnovení suverenity země. Spravedlnost a napravení pocitu křivdy v pojetí DSSS pak můžeme označit za nejdominantnějšś hodnotový rámec.

Výsledky výzkumu lze zasadit do širšího kontextu již proběhlých studií na podobné téma. Můžeme potvrdit např́klad tendence, které zmínil Turner (2013) ve své práci, když upozorňoval na náchylnost přecházet hranici ústavně konformního chování $\mathrm{v}$ prostředí sociálních médií a obecně internetu, a to s odvoláním na skutečnost, že se jedná pouze o virtuální realitu. Tomu napomáhá i současné nejasné vymezení právní hranice toho, co si je možno v prostředí internetu a potažmo na sociálních médiích dovolit. Zároveň se potvrdily i větší tendence $\mathrm{k}$ vyostřování diskuze a akceptaci násilí ve spojitosti $\mathrm{s}$ tzv. uprchlickou krizí, což potvrzuje závěry Feischmidta a Herviky (2015), kteří upozorňovali na vzrůstající tendence $\mathrm{k}$ radikalizaci spojené právě s antiimigračními protesty.

$\mathrm{Na}$ obecnějš́ rovině výsledky výzkumu zapadají do obecnější ideologické základny krajní pravice, jak ji představil např́klad Mudde (1995: 209-217), když definoval 5 pilírů krajní pravice - rasismus, xenofobii, nedemokratičnost, nacionalismus a silný stát. Všechna výše zmíněna mobilizační témata této charakteristice odpovídají, at' už jde o výše zmíněné rámování „cikánské kriminality“, snahu o silný stát nezávislý na mezinárodních institucích nebo zavádění faktoru etnicity v sociální politice. Pokud se tedy shodneme na tom, že DSSS můžeme zařadit do krajně pravicového spektra, lze konstatovat, že často uváděný základní rozdíl mezi západní a východní krajní pravici - tedy téma antiimigračních postojů, dlouho považované ve středoevropských reáliích za neaktuální či marginální (Strmiska a kol. 2005: 38-39, Pirro 2015: 82), v důsledku tzv. „migrační krize“ vymizel. Došlo tak, co se týče mobilizačních témat krajní pravice, $\mathrm{k}$ přiblížení západu a východu. V roce 2015 již toto téma tvoří většinu sledovaných prŕspěvků na facebookovém profilu DSSS a dominuje i v odezvě príźnivců strany.

Mezi dalšími tematickými oblastmi můžeme zmínit zaměření strany na otázku „cikánské kriminality“, kdy se strana staví proti Romům a podporuje „welfare šovinismus“, tedy podporu státu pro vlastní etnikum, kterou zmiňuje Mareš (2012), a kterou výsledky výzkumu potvrdily. Lze přitom doplnit, že protiromská 
a částečně i protiislámská témata jsou rámována jako napravování nespravedlností a welfare šovinismus je prezentován právě jako náprava křivd. Silný apel proti establishmentu napříc stranickým spektrem a obecná nespecifikovaná kritika systému, kterou zmiňuje ve své studii českých krajně pravicových subjektů napríklad Holas (2013) a potvrzuje ji i dřívější výzkum cílený prrímo na DSSS (Dlouhý, Brejchová, Háka 2014), je pak dalším silným mobilizačním tématem, které se promítlo i do výsledku našeho výzkumu.

\section{Závěr}

$\mathrm{Na}$ základě teoretického rámce, který se soustředil na oblast využití sociálních médií jako nástroje mobilizace a rámování, a s využitím obsahové a rámcové analýzy dat z facebookového profilu DSSS jsem identifikoval a popsal mobilizační témata, která tato strana využívá a která mají zároveň ohlas u prŕíznivců strany. Identifikoval jsem čtyři základní rámce, a to rámec protiislámský (potažmo protiimigračnî), pritiromský, protivládní a proti EU. Obecně je mobilizace stavěna na principu negace a vymezení se vůči jiným aktérům, především aktuálnímu establishmentu. Hodnotově vychází zejména z pocitu nespravedlnosti, která má svůj základ v údajném privilegování jistých aktérů ze strany vlády. Z výsledků pak vyplývá, že v posledních třech letech došlo $\mathrm{k}$ rychlé změně mobilizačního potenciálu, spojené především s posunem od protiromských mobilizačních témat $\mathrm{k}$ tématům imigrace a islámu.

Mezi dílčí výsledky analýzy patři zjištění, že okolo profilu strany se nezbudovala početnější a aktivnějši komunita; je možno předpokládat, že podporovatelé strany jsou spíše vázaní na konkrétní témata než na stranu jako takovou. Dále jsem identifikoval jednotlivé tematické kampaně, které DSSS $\mathrm{v}$ uplynulých třech letech prezentovala na svém profilu a jejichž vývoj rovněž kopíruje vývoj rámců - od protiromského tématu, který dominoval roku 2013, přes hledání nového nosného rámce $\mathrm{s}$ větším mobilizačním potenciálem $\mathrm{v}$ roce 2014, až k nalezení nového antiimigračnícho a antiislámského rámce, který dominoval roku 2015.

Budoucí výzkum krajní pravice by se mohl zaměřit několika směry. Jednou možností jsou hlubší narativní rozhovory s podporovateli krajně pravicových hnutí, s cílem odhalit jejich motivace a také způsoby, jak konkrétní rámce, které jsou jim předkládány, aplikují v každodenním životě. Obecněji by pak bylo rovněž prínosné zaměřit se na analýzu sociálních médií, jako nástroje mobilizace a radikalizace. Zde se nabízí napríklad výzkum modelování informačních sítí, které př́znivci dané strany nebo hnutí využívají. 


\section{Literatura a prameny}

Avukatu, Jiřina, Lupač, Petr (2014): „Analýza on-line sítě české krajní pravice.“ Rexter 12(1): 41-75.

Barnett, Brett (2007): Hate group community-building online: A case study in the visual content of internet bate. New York: Proceedings of the New York State Communication Association.

Bermingham, Adam a kol. (2009): „Combining Social Network Analysis and Sentiment Analysis to Explore the Potential for Online Radicalisation." In: Proceedings of the 2009 International Conference on Advances in Social Network Analysis and Mining. ASONAM '09, Washington, DC, USA, IEEE Computer Society (2009), 231-236.

Burris, Vall a kol. (2000): „White Supremacist Networks on the Internet.“ Sociological Focus 33(2): 215-235. DOI: 10.1080/00380237.2000.10571166

Bustikova, Lenka (2015): „The democratization of hostility Minorities and radical right actors after the fall of communism." In: Michael Minkenberg (ed.). Transforming the Transformation?: The East European Radical Right in the Political Process. Abingdon: Taylor and Francis Inc., 59-79.

Caiani, Manuela, Donatella Della Porta a Claudius Wagemann (2012): Mobilizing on the Extreme Right. Germany, Italy and the United States. Oxford: Oxford University Press.

Cammaerts, Bart (2009): „Radical pluralism and free speech in online public spaces: the case of North Belgian extreme right discourses." International Journal of Cultural Studies 12 (6): 555-575. DOI: 10.1177/1367877909342479

Cammaerts, Bart (2012): „Protest logics and the mediation opportunity structure.“ European Journal of Communication 27(2): 117-34. DOI: 10.1177/0267323112441007

Copsey, Nigel (2003): „Extremism on the net: the extreme right and the value of the Internet." In: Gibson, Rachel K., Paul Nixon a Stephen Ward (eds.). Political Parties and the Internet. London: Routledge, 218-231.

Della Porta, Donatela a Lorenzo Mosca (2006): „Democrazia in rete: stili di comunicazione emovimenti sociali in Europa." Rassegna Italiana di Sociologia, 4 (OctDec): 529-556.

Dlouhý, Miloš, Pavla Brejchová a Antonín Háka (2014): „Dělnická strana sociální spravedlnosti: terénní výzkum krajně pravicové strany. “ Rexter 12(1): 75-132.

DSSS (2015): „Protest 19. listopadu.“ Online (http://www.dsss.cz/report_-narodni-17_listopad-v-praze_-dsss-proti-imigraci-a-eu), ověřeno ke dni 21. 12. 2015.

Ekman, Mattias (2014): „The dark side of online activism.“ MedieKultur (56): 79-99. DOI: 10.7146/mediekultur.v30i56.8967

Feischmidt, Margi a Peter Hervik (2015): „Mainstreaming the Extreme: Intersecting Challenges from the Far Right in Europe." Intersections. East European Journal of Society and Politics 1(1): 3-17. DOI: 10.17356/ieejsp.v1i1.80

Ferber, Abby (2000): „Racial warriors and weekend warriors: The construction of masculinity in mythopoetic and white supremacist discourse." Men and Masculinities, 3(1): 30-56. DOI: 10.1177/1097184X00003001002

Gamson, William a Andre Modigliani (1989): „Media discourse and public opinion on nuclear power: A constructionist approach." American Journal of Sociology 95: 1-37.

Golder, Matt (2016): „Far Right Parties in Europe.“ The Annual Review of Political Science 19, 477-97. DOI: 10.1146/annurev-polisci-042814-012441 
Hájek, Martin (2014): Čtenár a stroj: Vybrané metody sociovédni analýzy textu. Praha: SLON. Háka, Antonín (2016): „Dělnická strana sociální spravedlnosti: postoj k systému.“ Politické vedy 19(1): 224-260.

Holas, Jakub (2013): Politický radikalismu a mládeそ̌. Institut pro kriminologii a sociální prevenci.

Hsieh, Hsiu-Fang a Sarah Shannon (2004): „Three approaches to qualitative content analysis." Qualitative health research 15(9): 1277-88. DOI: 10.1177/1049732305276687

Chau, Michael a Jennifer Xu (2007): „Mining communities and their relationships in blogs: A study of online hate groups." International Journal of Human-Computer Studies 65(1): 57-70. DOI: 10.1016/j.ijhcs.2006.08.009

Choo, Kim-Kwang Raymond (2008): „Organised crime groups in cyberspace: a typology." Trends in organized crime 11(3): 270-295. DOI: 10.1007/s12117-008-9038-9

Knott, Daniel (2015): Hands-On Mobile APP Testing. Guide for Mobile Testing and Anyone Involved in the Mobile APP Business. Addison-Wesley.

Mareš, Miroslav (2011): „Czech Militant Democracy in Action: Dissolution of the Workers' Party and the Wider Context of This Act." East European Politics and Societies (published online before print): 33-55. DOI: 10.1177/0888325411408070

Mareš, Miroslav (2012): Pravicový extremismus v Ceské republice. Praha: Friedrich-EbertStifung.

Mareš, Miroslav (2015): „The impact of the Czech radical right on transformation and (de-)consolidation of democracy after 1989.“ In Holzer, Jan a Miroslav Mareš (eds). Challenges To Democracies in East Central Europe. Abingdon: Routledge, 2016. s. 59-14.

Mareš, Miroslav a Petra Vejvodová (2010): „Dělnická strana: profil české pravicově extremistické strany.“ Rexter 8(2): 42-74, Online (http://www.rexter.cz/delnicka-stranaprofil-ceske-pravicove-extremisticke-strany/), ověřeno ke dni 21. 12. 2015.

Mudde, Cas (1995): „Right-Wing Extremism Analyzed. A Comparative Analysis of the Ideologies of Three Alleged Right-Wing Extremist Parties (NPD, NDP, CP'86)."European Journal of Political Research 27(2): 203-224. DOI: 10.1111/j.14756765.1995.tb00636.x

O'Callaghan, Derek a kol. (2012): „An Analysis of Interactions Within and Between Extreme Right Communities in Social Media." Ubiquitous Social. Media Analysis Volume 8329 of the series Lecture Notes in Computer Science s. 88-107.

Payne, Judy a Geoff Payne (2004): Key concepts in social research. Thousand Oaks: Sage.

Peters, Rikke Alberg (2015): „Mediatized Extreme Right Activism and Discourse.“ Media@LSEWorking, Paper \#32.

Pirro, L. P. Andrea (2015): „The populist radical right in the political proces.“ In Holzer, Jan a Miroslav Mareš (eds.). Challenges To Democracies in East Central Europe. Abingdon: Routledge, 80-105.

Post, Jerrold (2005): „Psychology.” Addressing the Causes of Terrorism, Report of the working group at the International Summit on Democracy, Terrorism and Security, 8-11, Madrid, The Club de Madrid Series on Democracy and Terrorism, 1, 7-12.

Ramalingam, Vidhya (2014): „Old Threat, New Approach Tackling the Far Right Across Europe.“ Institute for Strategic Dialogue.

Rieder, Bernard (2013): Studying Facebook via Data Extraction: The Netvizi. Application. Online (http://rieder.polsys.net/files/rieder_websci.pdf), ověřeno ke dni 21.12. 2015.

Rozsudek. Nejoyššího správníbo soudu ze dne 17. 2. 2010, sp. zn. Pst 1/2009. 
Sartori, Giovanni (2005): Strany a stranické systémy. Schéma pro analýzu. Brno: Centrum pro studium demokracie a kultury (CDK).

Snow, David a Robert Benford (1992): „Master Frames and Cycles of Protest.” In Morris, Aldon D a Carol Mueller (eds.), Frontiers in Social Movement Theory. New Haven: Yale University Press, 133-155.

Strmiska, Maxmilián a kol. (2005): Politické strany moderni Evropy: analyza stranicko-politických systémui. Praha: Portál.

Thiesmeyer, Lynn (1999): „Racism on the Web: Its rhetoric and marketing.“ Ethics and Information Technology 1(2): 117-125. DOI: 10.1023/A:1010090811116

Tilly, Charles (2006): Politika kolektivního násilí. Praha: Sociologické nakladatelství.

Turner, Eric (2013): „New Movements, Digital Revolution and Social Movement Theory.“ A Journal of Social Justice 25(3): 376--383. DOI: 10.1080/10402659.2013.816562

Van Aelst, Peter a Stefaan Walgrave (2002): „New media, new movements? The role of the Internet in shaping the 'Anti-globalization' movement, Information." Communication \& Society 5(4): 465-93. DOI: 10.1080/13691180208538801

Wang, Jing a kol. (2015): „Effect of Media Usage Selection on Social.“ PLOS ONE 10(9): e0134811. DOI: 10.1371 /journal.pone.0134811

\section{Identification of Workers' Party of Social Justice (DSSS) mobilization issues using a social media analysis \\ SUMMARY}

The article "Identification of Workers' Party of Social Justice mobilization issues using a social media analysis" fits into the theme of using social media as a tool for extremism and radicalism in the case of far-right Czech parties. In the case study, we tried to answer the question: What topics of the Workers' Party of Social Justice (DSSS) are successful in mobilizing their supporters? Based on the theoretical framework, we focused on the use of social media as a tool for mobilization and framing. Using content and frame analyses of data from the Facebook profile of DSSS, we have identified and described mobilization issues that are used by this party and that are also popular with the supporters of the party.

To answer the research questions, we chose a qualitative research design with a special focus on data obtained from the party's Facebook page. We used the Netvizz application to extract the data. The initial dataset consisted of 1,255 posts. These posts are used in the initial phase of the research to determine patterns of both user and party behaviour Facebook. In the advanced analysis, the dataset was filtered out to posts with the most user responses. The posts with an above-average response rate were selected and analysed through content and frame analyses.

Based on our analysis, we can conclude that DSSS uses its Facebook page very actively and regularly for self-presentation and for framing particular mobilization issues. We identified four fundamental frameworks, namely anti-Islamic (hence anti- 
immigration), anti-Roma, anti-government and anti-EU frames. General mobilization is built on the principle of negation and delimitation towards other actors, namely the establishment.

The most reflected themes in 2013 were the anti-Roma theme and the Parliamentary elections. The next year, 2014, was thematically more varied and, except for the antiRoma theme, the most reflected themes were calls to restore the death penalty and local elections. In the monitored part of 2015, the greatest activity of the supporters of the party was associated with anti-immigrant and anti-Islamic topics.

With respect to development over time, the anti-Roma mobilization theme has experienced the biggest changes. This theme dominated in 2013, but it was reflected only marginally in subsequent years. This change was not caused by a change of attitude toward this topic, but mostly because it was overshadowed by immigration and antiMuslim themes. These themes began to appear to a larger extent in 2014 and completely dominated the mobilization themes of DSSS in 2015. Changes in the distribution of these themes can be seen even from the perspective of the party itself. After the failed elections in 2013 the party began to search for another theme and programme and, due to the current "refugee crisis", it found such themes in the opposition to immigration and Islam.

All mentioned frames used by the party are very straightforward and always contain a clearly identified problem, culprit and solution. Roma and immigrants share a large part of the framing and from the perspective of DSSS they are referred to as "Parasites" who abuse the resources of the state which they do not deserve and which should only serve citizens or ethnic Czechs. For immigrants, and hence Muslims in general, the frame is complemented by a value component where Islam is put into opposition with Western values. The solutions that the party offers are very resolute and simplified. At the contextual level, the party seeks to get votes that could be used to rectify injustice against Czech citizens and restore the country's sovereignty. Justice and the righting the wrongs can be described as the most dominant value frame in the concept of DSSS.

If we consider the results of our study within the wider context of research that has already taken place, we can confirm, for example, the tendencies mentioned by Turner (2013) in his work when he pointed out the tendency to cross the boundaries of constitutional behaviour in the environment of social media and the internet in general, referring to the fact that it is just a virtual reality. This is supported by the current unclear legal boundaries of what can and cannot be done on the internet and hence in the social media environment. At the same time, even greater tendencies to escalate the discussions and accept violence in connection to the so-called "refugee crisis!" have been proven; this confirms the conclusions of Feischmidt and Hervika (2015) who highlighted the increasing tendencies of radicalization associated with anti-immigrant protests. So, if we agree on the classification of DSSS as far-right party, we can conclude that the difference between the western and eastern far-right wing often mentioned as one of the principal themes of anti-immigrant attitudes, which was considered obsolete or marginal for long period in the east (Strmiska et al. 2005: 38-39, Pirro 2015: 82), has disappeared as a result of the "refugee crisis". As for the mobilization themes of the far-right wing, there is a significant convergence of west and east. In 2015, this theme constitutes a majority of the monitored posts on the Facebook page of the party and also dominates in terms of responses of the supporters of the party. 


\section{Př́lohy}

Tabulka č. 2: Jednotlivé rámce DSSS a jejich propojení

\begin{tabular}{|c|c|c|c|c|}
\hline & $\begin{array}{l}\text { Vymezení se } \\
\text { proti: }\end{array}$ & Tematicky rámec (KRIZE) & $\begin{array}{l}\text { Kontextuální rámec } \\
\text { (KONTEXT) }\end{array}$ & Hlavní rámec (IDEJE) \\
\hline \multirow{3}{*}{$\begin{array}{l}\text { Diagnostický } \\
\text { rámec } \\
\text { (PROBLÉM) }\end{array}$} & Romům & $\begin{array}{l}\text { Nepřizpůsobiví občané, zlodějné } \\
\text { cikánské organizace } \\
\text { Pozitivní diskriminace }\end{array}$ & \multirow{3}{*}{$\begin{array}{l}\text { Krize vládnutí v ČR } \\
\text { a Evropé. Vina je dávána } \\
\text { celému polistopadovému } \\
\text { stranickému spektru } \\
\text { s náznaky kritiky celého } \\
\text { systému. } \\
\text { Především protivládní } \\
\text { kontext se mění z hlediska } \\
\text { závislosti na dalších } \\
\text { mobilizačních tématech. }\end{array}$} & $\begin{array}{l}\text { Nespravedlnost } \\
\text { Chybějící ochrana } \\
\text { "slušných" občanů } \\
\text { Chybějící nacionální } \\
\text { podpora }\end{array}$ \\
\hline & Establishmentu & $\begin{array}{l}\text { Zkorumpovaná a neschopná vláda } \\
\text { Diktatura Bruselu }\end{array}$ & & $\begin{array}{l}\text { Ohrožení suverenity státu } \\
\text { a ohrožení českých } \\
\text { národních zájmů }\end{array}$ \\
\hline & Imigrantům & $\begin{array}{l}\text { Př́liv imigrantských hord } \\
\text { "Pozitivní diskriminace" } \\
\text { aplikovaná na imigranty } \\
\text { Ohrožení českých kulturních } \\
\text { hodnot }\end{array}$ & & $\begin{array}{l}\text { Islámská Evropa, zánik } \\
\text { evropských hodnot } \\
\text { Nespravedlnost }\end{array}$ \\
\hline \multirow{3}{*}{$\begin{array}{l}\text { Prognostický } \\
\text { rámec } \\
\text { (řEŠENÍ) }\end{array}$} & Romům & $\begin{array}{l}\text { Konec pozitivní diskriminace, } \\
\text { sociální dávky pro ty, co si to } \\
\text { zaslouží }\end{array}$ & \multirow{3}{*}{$\begin{array}{l}\text { Zvolení DSSS do } \\
\text { zastupitelských úřadů }\end{array}$} & $\begin{array}{l}\text { Zavedení "spravedlivého" } \\
\text { režimu }\end{array}$ \\
\hline & Establishmentu & Sesazení vlády, vystoupení z EU & & Hájení českých zájmů \\
\hline & Imigrantům & $\begin{array}{l}\text { Uzavření hranic, nepřijímání } \\
\text { imigrantů, vyhoštění těch co již } \\
\text { jsou v Evropě, restrikce vůči těm } \\
\text { kteří imigraci schvalují }\end{array}$ & & $\begin{array}{l}\text { Silný národní stát postavený } \\
\text { na suverenitě a nacionalismu }\end{array}$ \\
\hline
\end{tabular}




\begin{tabular}{|c|c|c|c|c|}
\hline $\begin{array}{l}\text { Mobilizační } \\
\text { rámec } \\
\text { (PROSTřEDKY) }\end{array}$ & $\begin{array}{l}\text { Establishmentu } \\
\text { Imigrantům }\end{array}$ & $\begin{array}{l}\text { Demonstrace, pochody a protest } \\
\text { proti nečinnému státu, policii, } \\
\text { nepřizpůsobivým, lidskoprávním } \\
\text { aktivistům "vlastizrádcům" atd. }\end{array}$ & $\begin{array}{l}\text { Mobilizace potencionálních } \\
\text { voličů - silná artikulace } \\
\text { nutnosti volby DSSS }\end{array}$ & $\begin{array}{l}\text { Náprava nespravedlnosti a } \\
\text { křivd } \\
\text { Taktika: Akcelerace } \\
\text { násilných akcí } \\
\text { Zachování suverénního } \\
\text { českého národa } \\
\text { Taktika: Zostřování rétoriky, } \\
\text { které se někdy pohybuje za } \\
\text { hranou demokratického } \\
\text { politického rámce } \\
\text { Ochrana země pro budoucí } \\
\text { generace } \\
\text { Taktika: Zostřování rétoriky, } \\
\text { která se někdy pohybuje za } \\
\text { hranou demokratického } \\
\text { politického rámce }\end{array}$ \\
\hline & & KRÁTKODOBÝ HORIZONT & $\begin{array}{l}\text { STŘEDNĚDOBÝ } \\
\text { HORIZONT }\end{array}$ & \\
\hline
\end{tabular}

Zdroj: Autor na základě sesbíraných dat. 